\title{
2. BULK MINERALOGY OF NONBIOGENIC SEDIMENTS FROM ODP SITES 642 AND 643, NORWEGIAN SEA: IMPLICATIONS FOR SEDIMENT PROVENANCE AND RECYCLING ${ }^{1}$
}

\author{
Lawrence A. Krissek ${ }^{2}$
}

\begin{abstract}
Bulk mineralogy of the nonbiogenic fraction of 61 samples from ODP Sites 642 and 643 in the Norwegian-Greenland Sea has been determined by X-ray diffraction, using an internal standard method. These data were used to investigate patterns of sediment provenance (source rock lithology and weathering). Important phases are smectite, chlorite, illite, kaolinite, quartz, and plagioclase feldspar. At both sites, smectite abundances increase downcore, while quartz and illite abundances decrease. Kaolinite, chlorite, and plagioclase feldspar abundances are variable throughout the length of the cores. These compositional changes suggest that moderately-weathered acidic source rocks become more important in younger sediments. The acidic source replaces a basic source that is dominant near the base of each section. Kaolinite was recycled from Paleozoic and Mesozoic sedimentary rocks and paleosols, while variable chlorite abundances record heterogeneity of source lithology and weathering regime on the Scandinavian landmass.

By means of principal-components analysis of the mineral abundance data we have identified four major source areas that supplied sediments to these sites. Source area compositions and their relative influences through time are similar to the provenance record interpreted from mineral abundances. A paleoclimatic history inferred from the provenance record compares favorably with other records interpreted previously from marine micropaleontologic and terrestrial palynologic data from this area.
\end{abstract}

\section{INTRODUCTION}

One of the major scientific objectives of Leg 104 of the Ocean Drilling Program was to recover sediments from a transect of sites across the modern Norwegian Current, to evaluate the paleoclimatic, paleoceanographic, and paleobiogeographic history of the Norwegian-Greenland Sea. To accomplish this objective, sites were located in areas where sedimentation has been dominated by hemipelagic and pelagic processes, with minimal indication of bottom-transport activity (Eldholm, Thiede, et al., 1987; Fig. 1). While these sites were chosen to provide complete stratigraphic and micropaleontologic successions, the dominance of hemipelagic and pelagic deposits precludes the recovery of significant coarse-grained (sand-size and larger) terrigenous material. The general absence of coarse-grained terrigenous material (especially in the pre-late Pliocene portion) in turn limits investigations of terrigenous component provenance via conventional petrographic techniques. Instead, these finegrained terrigenous components are suitable for examination by $\mathrm{X}$-ray diffractometry (XRD).

General relationships between the lithology and the weathering regimes of a source area and the composition of the clay mineral assemblage derived from that source area were established on a global scale by Griffin et al. (1968) and Lisitzin (1972). Those relationships can be summarized as follows:

1. Smectites, the family of $2: 1$ phyllosilicates that is expandable from a $14 \AA$ to a $17 \AA$ basal spacing, are developed by continental or submarine chemical alteration of basic igneous rocks.

2. Chlorites, the family of $2: 1: 1$ phyllosilicates with a $14 \AA$ basal spacing, are developed by physical weathering of basic source rocks and are especially common at high latitudes.

3 . Illites, the family of $2: 1$ phyllosilicates with a $10 \AA$ basal spacing, are developed by moderate weathering of acidic source

\footnotetext{
${ }^{1}$ Eldholm, O., Thiede, J., Taylor, E., et al., 1989. Proc. ODP, Sci. Results, 104: College Station, TX (Ocean Drilling Program).

2 Department of Geology and Mineralogy, The Ohio State University, Columbus, $\mathrm{OH} 43210$.
}

rocks in temperate climates, and are especially common at middle latitudes.

4. Kaolinites, the family of $1: 1$ phyllosilicates with a $7 \AA$ basal spacing, are developed by intense chemical weathering in warm, humid climates, and are especially common at low latitudes.

Numerous other studies have confirmed such relationships on basin-wide (Biscaye, 1965; Kolla and Biscaye, 1973; Kolla et al., 1976) and local or regional scales (e.g., Pinet and Morgan, 1979; Karlin, 1980; Rosato and Kulm, 1981). As a result, a common investigative approach is to interpret continental source lithologies and/or weathering patterns from clay mineral assemblages by applying these relationships. Such studies, however, generally examine only the clay minerals (phyllosilicates) present in the $<2-\mu \mathrm{m}$ size fraction, and determine their abundances semiquantitatively (generally following the method of Biscaye, 1965). This analytical method does not include provenance information carried by the silts or the clay-sized nonphyllosilicates. In addition, variations in the diffracting properties of a particular clay mineral may complicate comparison of semiquantitative mineral abundances between study areas.

Fan (1976) demonstrated that the silt-size fraction of fluvial samples carried approximately the same compositional signature as sands derived from the same sources, although the silts were depleted in heavy and accessory minerals. For sediments such as those recovered during Leg 104, therefore, an analysis that includes the silts can provide provenance information that is otherwise unavailable. Including silt-sized material violates several assumptions of the analytical method of Biscaye (1965), however, requiring that a different technique be used. Gibbs (1967) proposed such a technique, which involves adding an internal standard to each sample. The technique can be applied to all grain sizes and minerals. This technique was applied successfully by Scheidegger and Krissek (1982) and Krissek (1984) to trace dispersal patterns of several grain-size fractions off Peru/ Chile and Oregon/Washington, respectively.

Previous studies of sediment provenance on the Vøring Plateau have generally used materials recovered during DSDP Leg 38 (Talwani, Udintsev, et al., 1976). White (1978a) used the Bis- 


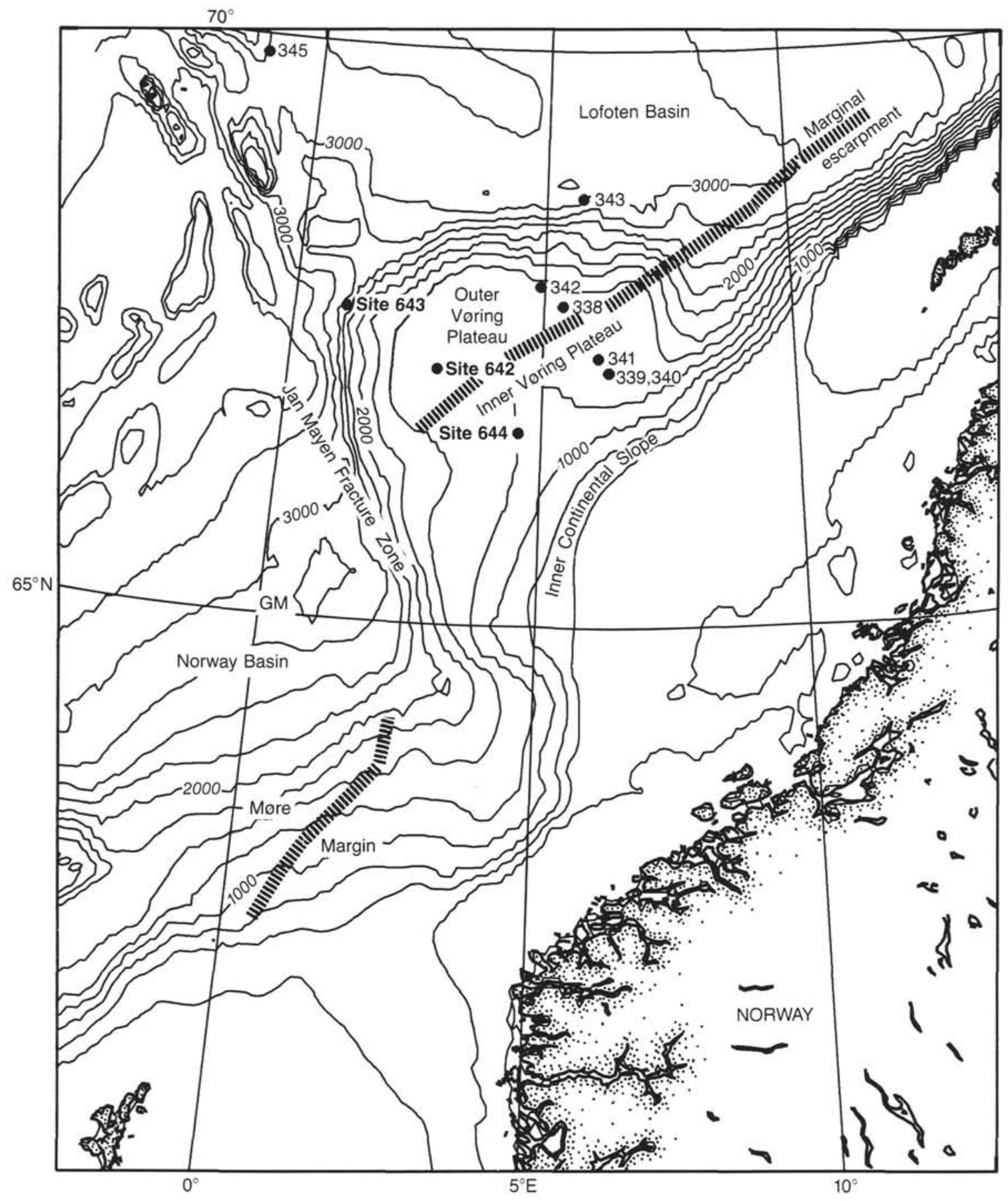

Figure 1. Bathymetric map of the Vøring Plateau showing the locations of ODP Sites 642, 643, and 644 (from Eldholm, Thiede, Taylor, et al., 1987). Contour interval $250 \mathrm{~m}$.

caye (1965) method to determine semiquantitative clay mineral abundances in a limited suite of samples from these cores. At Site 338, smectite abundances decreased markedly from the lower Eocene to the lower Miocene, and decreased slightly from the lower Miocene to the middle/upper Miocene. Illite abundances varied significantly throughout the pre-Pliocene section. Chlorite was more abundant than kaolinite in the lower Eocene, but the two components were subequal in abundance during the lower Miocene to middle/upper Miocene. At Site 341 , only middle Miocene sediments were analyzed. Their compositions averaged approximately 20 to $30 \%$ smectite, 30 to $40 \%$ illite, $20 \%$ kaolinite, and $14 \%$ chlorite. Correlative sediments at Site
338 contained slightly more illite and correspondingly less smectite. White (1978b) used the compositional data, together with other information, to interpret the depositional history of the Vøring Plateau, but he identified sediment provenance in only a general manner. He concluded that Paleocene sediments probably reflect terrigenous influx from Norway as well as erosion off the early rifted boundary of the Norwegian Sea, while younger sediments may record a relative uplift of Norway during the Tertiary. Emelyanov, Blazchisin, et al. (1978) also examined the sedimentary history of the Vøring Plateau, using heavy and light fraction silt mineralogy and sediment geochemistry. Their major conclusion with respect to provenance was that volcanic 
input was more important during Miocene sedimentation on the Vøring Plateau than during the Pliocene and Pleistocene.

The objective of this study is to investigate the provenance record preserved in the Cenozoic sedimentary sequences recovered at ODP Sites 642 and 643, using a modification of the technique of Gibbs (1967). The compositional data alone provide a more detailed provenance record for the Vøring Plateau than those developed by White (1978b) and Emelyanov, Blazchisin, et al. (1978), but are limited because individual minerals are not necessarily diagnostic of particular source lithologies or weathering patterns. To clarify the provenance history, principal-components analysis of the mineral abundance data is used to outline source area compositions, which are interpreted to reflect combinations of source rock lithology and weathering regime. The relative importance of each source area at each stratigraphic level then traces the evolution of sediment provenance through the sequences. This provenance record provides insight to the paleogeographic and paleoclimatic evolution of adjacent landmasses, and complements paleoclimatic interpretations developed from paleontologic data.

\section{GENERAL LITHOSTRATIGRAPHY AND AGE CONTROL, LEG 104}

The lithostratigraphies of ODP Sites 642 and 643 are summarized here to provide the sedimentary context of the samples analyzed for this study. The lithostratigraphies are described in detail by Eldholm, Thiede, Taylor, et al. (1987), and the age assignments are from Bleil (this volume). Site 642 (Fig. 1) was located on the outer Vøring Plateau, and the sedimentary sequence recovered there was divided into four lithologic units. Unit I [0-60 meters below seafloor (mbsf)], is composed of upper Pliocene to Holocene interbedded dark, carbonate-poor glacial muds and light, carbonate-rich interglacial sandy muds. Unit II (60-157 mbsf) was divided into four subunits, ranging from late Miocene to Pliocene in age: nannofossil oozes; siliceous muds and oozes; interbedded nannofossil oozes, siliceous nannofossil oozes, and siliceous muds and oozes; and mixed siliceous muds and oozes. Unit III (157-277 mbsf) is composed of lower to middle Miocene siliceous muds and oozes, while Unit IV (277-315 mbsf) is composed of Eocene to lower Miocene volcaniclastics and altered volcaniclastic muds, sandy muds, and sands. The Pleistocene/Pliocene, Pliocene/Miocene, upper/ middle Miocene, and middle/lower Miocene boundaries were identified at approximately 53, 80, 175, and $210 \mathrm{mbsf}$, respectively.

Site 643 was located near the base of the outer Vøring Plateau (Fig. 1), and the sedimentary sequence recovered there was subdivided into five lithologic units. Unit I ( $0-50 \mathrm{mbsf})$ is composed of upper Pliocene to Holocene interbedded dark, carbonate-poor and light, carbonate-rich muds and sandy muds. Unit II (50-100 mbsf) is composed of middle Miocene to lower Pliocene siliceous nanofossil oozes, terrigenous siliceous muds, and diatomaceous nannofossil oozes, and is affected by slumping. Unit III (100-274 mbsf) is composed of Miocene diatomaceous oozes. Unit IV (274-401 mbsf) is composed of lower Miocene compaction-laminated mudstones, while Unit V (401-565 mbsf) is composed of Oligocene zeolitic mudstone and altered pyroclastic sediments. At Site 643, the Pliocene/Miocene, upper Miocene/middle Miocene, middle Miocene/lower Miocene, and Miocene/Oligocene boundaries are located at approximately $67,115,225$, and 400 mbsf, respectively.

\section{ANALYTICAL METHODS AND MATERIALS}

Twenty-eight samples from Site 642 and 33 samples from Site 643 were analyzed by X-ray diffractometry (XRD). No material from Site 644 was examined because of the limited age of sediments recovered there. The samples used for this study were residues that remained after shipboard carbonate determinations by carbonate bomb and Coulometer techniques (Eldholm, Thiede, Taylor, et al., 1987). Biogenic and detrital carbonate components were removed from these samples by treatment with $\mathrm{HCl}$ during carbonate analysis, but the general agreement between these data and shipboard XRD analyses of untreated samples indicates that detrital mineralogy was not significantly affected by the $\mathrm{HCl}$ treatment. Shipboard smear-slide data (Eldholm, Thiede, Taylor, et al., 1987) also indicate that detrital carbonate is not a major sediment constituent at these sites. Sampling interval was approximately one sample per core, or approximately one sample every $10 \mathrm{~m}$; sampling at Site 642 extended to $270 \mathrm{mbsf}$ while the deepest sample at Site 643 was taken at $355 \mathrm{mbsf}$. Deeper samples were not analyzed because shipboard Xray diffraction data indicated consistent smectite-dominated compositions below these levels (Eldholm, Thiede, Taylor, et al., 1987).

Sample preparation followed the general procedure outlined by Scheidegger and Krissek (1982) and Krissek (1982), although samples were not size-fractionated prior to analysis. Approximately $100 \mathrm{mg}$ of dried bulk sample (residue of carbonate analysis) were weighed and mixed with $10 \%$-by-weight boehmite $(\mathrm{A} 100 \mathrm{H})$, which serves as an internal standard. These mixtures were back-loaded as powders into random mounts for XRD analysis.

All slides were solvated with warm ethylene-glycol vapor for 8-12 hr immediately preceding analyses on a Philips diffractometer. Slides were scanned at a rate of $1^{\circ} 2 \theta$ per min with Ni-filtered CuK $\alpha$ radiation. Detector time constant was $0.5 \mathrm{~s}$, and data were plotted on a strip-chart recorder. The 15- to $18-\AA$ smectite $(001), 10-\AA$ illite $(001), 6.11-\AA$ boehmite (020), 4.26- $\AA$ quartz (100), and 4.02- $\AA$ plagioclase (201) peak areas were measured with a polar planimeter. The $3.57-\AA$ kaolinite $(002)$ and $3.54-\AA$ chlorite $(004)$ peaks were scanned on each sample at $0.5^{\circ} 2 \theta$ per min to differentiate chlorite and kaolinite; these data were also plotted on a strip-chart recorder, and peak areas were measured with a polar planimeter.

Under conditions of uniform grain size and uniform mineral chemi$\mathrm{cal} / \mathrm{structural}$ composition, calibration curves can be constructed to calculate mineral abundances from mineral/boehmite peak area ratios (Gibbs, 1967; Scheidegger and Krissek, 1982; Krissek, 1982, 1984). The samples from Sites 642 and 643 do not meet these conditions, however, in several important ways. First, bulk samples were analyzed so that grain sizes within the pressed powders were not uniform and orientation effects may have been important. Second, clay mineral compositions and crystallinities vary stratigraphically (e.g., changes in smectite composition, as outlined in Eldholm, Thiede, Taylor, et al., 1987), which can change the diffracting properties of a particular mineral through the sample suite (Krissek and Scheidegger, 1983). Because the samples used in this study do not fulfill the criteria needed to accurately apply calibration curves, the mineral/boehmite peak area ratios measured in this study have not been converted to mineral abundances. Instead, the data have been left as peak-area ratios. Variations in the abundance of a single mineral (e.g., quartz) can be described using downcore changes in the peak-area ratio of that mineral. The absolute abundances of two or more minerals, however, cannot be compared.

Analytical precision was evaluated by analyzing replicate slides of five samples, and is estimated at approximately $+15 \%$ of the peak-area ratio for smectite, illite, plagioclase, and kaolinite, $+8 \%$ of the peakarea ratio for chlorite, and $+2 \%$ of the peak-area ratio for quartz.

Under conditions of uniform grain size and mineral homogeneity, Scheidegger and Krissek (1982) and Krissek (1982) have demonstrated that absolute abundances, determined from mineral/boehmite peak-area ratios using calibration curves, are accurate at $+5 \%$ for smectite, $+2 \%$ for chlorite and illite, and $+1 \%$ for quartz and plagioclase feldspar. Absolute abundances inferred from the peak-area ratios measured in this study would have lower accuracies than those cited by Scheidegger and Krissek (1982) and Krissek (1982), because of the grain-size and compositional variations described earlier.

The peak-area ratio data from Sites 642 and 643 were examined for sample-to-sample relationships by principal-components analysis, using the PRINCOMP procedure of the SAS software package (SAS Institute, Inc., 1985). The PRINCOMP procedure weights all variables equally and examines the variance-covariance matrix, so the analysis is equivalent to Q-mode factor analysis as widely cited in the sedimentologic literature (Davis, 1986). The final PRINCOMP results were obtained by a VARIMAX rotation of only the three most important principal compo- 
nents, because those three principal components included variations in all the minerals present.

\section{DATA}

Mineral/boehmite peak-area ratios are plotted as a function of depth downcore at Sites 642 and 643 in Figures 2 and 3, respectively. At Site 642, smectite content is variable, with significant increases above the present value at approximately 55 and 250 mbsf. Illite and quartz abundances generally decrease downcore, while plagioclase feldspar abundances are more variable, but also generally decrease downcore. Kaolinite and chlorite abundances are dominated by short-term variability with no obvious downcore trend. The boundary between lithologic Units I and IIa coincides with distinct changes in several peak-area ratios, especially those of smectite and illite; other lithologic boundaries are not readily identifiable in the peak-area ratio plots. The absence of sharp changes in peak-area ratios at lithologic boundaries reflects the importance of biogenic carbonate and silica in defining lithologic Units II and III (Eldholm, Thiede, Taylor, et al., 1987).

Peak-area ratios at Site 643 show downcore patterns that are quite similar to those displayed at Site 642. Smectite abundances again increase in two distinct steps; one occurs at approximately $46 \mathrm{mbsf}$ (the base of Unit I), while the second increase is located at approximately 290 mbsf. Illite and quartz ratios generally decrease downcore. Plagioclase feldspar, kaolinite, and chlorite ratios are variable above $270 \mathrm{~m}$, but are generally low below that level. As at Site 642, the boundary between lithologic Units I and IIa is marked by abrupt changes in several peak area-ratios. Lithologic boundaries within Unit II and between Units II and III are not recorded by noticeable changes in detrital mineralogy, again reflecting the importance of biogenic components in defining those units (Eldholm, Thiede, Taylor, et al., 1987). The marked increase in smectite abundance and the decrease in plagioclase, kaolinite, and chlorite abundances at 270 to 290 mbsf are closely associated with the boundary between lithologic Units III and IV.

\section{DISCUSSION}

\section{Provenance Interpretations Based on Mineral Abundances}

As described above, several consistent compositional changes are observed downcore at Sites 642 and 643. Applying the general source area/clay mineral relationships discussed previously suggests that the dominant sediment source to this area changed through time. Sediments from the base of Unit III at Site 642 and from Unit IV at Site 643 are dominated by smectite, and are interpreted to have been derived mostly from alteration of basic volcanic material. Much of this alteration may have occurred in situ, as suggested by the ash-rich nature of Unit IV at both sites (Eldholm, Thiede, Taylor, et al., 1987). Cristobalite was also observed in samples from Unit IV at Site 643; this cristobalite may have formed during alteration of volcanic ash (Wilding, et al., 1977), but may also be either detrital or a diagenetic product formed from biogenic silica (Blatt, et al., 1980).

Smectite ratios are lower in Units I to III than in Unit IV at each site, while illite, quartz, and plagioclase feldspar ratios are generally higher. This change records the increased importance of moderately-weathered continental (acidic) terranes as the depositional sites migrated away from regions of active volcanism. Such continental source terranes contain acidic igneous and/or metamorphic lithologies and pre-existing sedimentary rocks, and are common throughout Norway (Holtedahl, 1960; Nicholson, 1974); these data do not uniquely identify a single region as the probable source.
The major compositional changes above the base of Unit III at each site are continued increases in quartz, illite, and plagioclase feldspar ratios upsection. Because the chlorite and kaolinite values do not consistently decrease upsection, the upcore increase in the other continental phases (illite, quartz, and plagioclase feldspar) suggests that some nonquantified component is diluting these phases in lithologic Units 1 and II. As mentioned previously, biogenic components are abundant-to-dominant in Units III and II at both sites; although biogenic carbonate was removed from these samples prior to analysis, biogenic opal was still present. The gradual upcore increase in illite, quartz, and plagioclase feldspar ratios, therefore, reflects the decreasing importance of biogenic silica from Unit III to Unit I. This trend is also observable in smear-slide data from the two sites (Eldholm, Thiede, Taylor, et al., 1987).

The variable presence of chlorite and kaolinite throughout Sites 642 and 643 provides an unusual assemblage for provenance interpretation, since kaolinite is generally considered a lowlatitude, chemically-weathered product, while chlorite is commonly developed in high-latitude, physically-weathered zones. This apparent contradiction in weathering conditions, however, only exists if both phases are first-generation weathering products. If one phase is recycled from preexisting deposits, then its occurrence carries no information about contemporaneous weathering conditions.

Kaolinites have been observed in a number of sedimentary sequences of Mesozoic and Cenozoic age throughout the North Sea/Norwegian-Greenland Sea/British Isles/Scandinavia region. Seafloor sediments that contain kaolinite have been reported from the upper Quaternary of the North Sea and the Norwegian-Greenland Sea (Eisma and van der Gaast, 1983), the upper Quaternary of the Skaggerak (Rosenqvist, 1985), the upper Quaternary of the Norwegian continental shelf (Holtedahl, et al., 1974; Halvorsen, 1974), the Cenozoic of the Norwegian continental shelf (Bugge, et al., 1975), the Tertiary of the North Sea (Nielsen, 1979), an Eocene lateritic paleosol recovered at DSDP Site 336 on the Iceland-Faeroe Ridge (Nilsen and Kerr, 1978), and the Jurassic-through-Cretaceous of the mid-Norwegian continental shelf (Bugge, et al., 1984). Sedimentary sequences that are exposed subaerially and contain kaolinite have been reported from the Miocene of central Jutland (Friis, et al., 1979), the Jurassic of northeastern Scotland (Hurst, 1985), and a Jurassic paleosol at Andøy in northern Norway (Dalland, 1975; Sturt, et al., 1979).

The sequences at Andøy, northeastern Scotland, and the mid-Norwegian continental shelf indicate that climatic conditions suitable for kaolinite formation existed in northern Europe during several intervals of the Paleozoic and the Mesozoic. The Cretaceous sequence on the mid-Norwegian continental shelf contains a mixture of kaolinite, illite, chlorite, and mixedlayer clays, as well as recycled Jurassic and lower Cretaceous palynomorphs. Because of the compositional stability of kaolinite under most natural weathering conditions (Garrels and McKenzie, 1971) and its dominance lower in the section, Bugge, et al. (1984) concluded that the kaolinite was also recycled from Jurassic and lower Cretaceous deposits. Friis, et al. (1979) also recognized the importance of recycling in the Miocene sequence of central Jutland, where abundant kaolinite, abundant reworked Carboniferous megaspores, and minor Mesozoic (Jurassic?) megaspores are observed. Friis, et al. (1979) concluded that the kaolinite and the organic components were recycled from preexisting sedimentary sources to the west and the northwest. These two conclusions, together with the studies of the Jurassic kaolinites of northeastern Scotland (Hurst, 1985) and the Jurassic kaolinite paleosol at Andøy, Norway (Dalland, 1975; Sturt, et al., 1979), indicate that conditions favoring ka- 


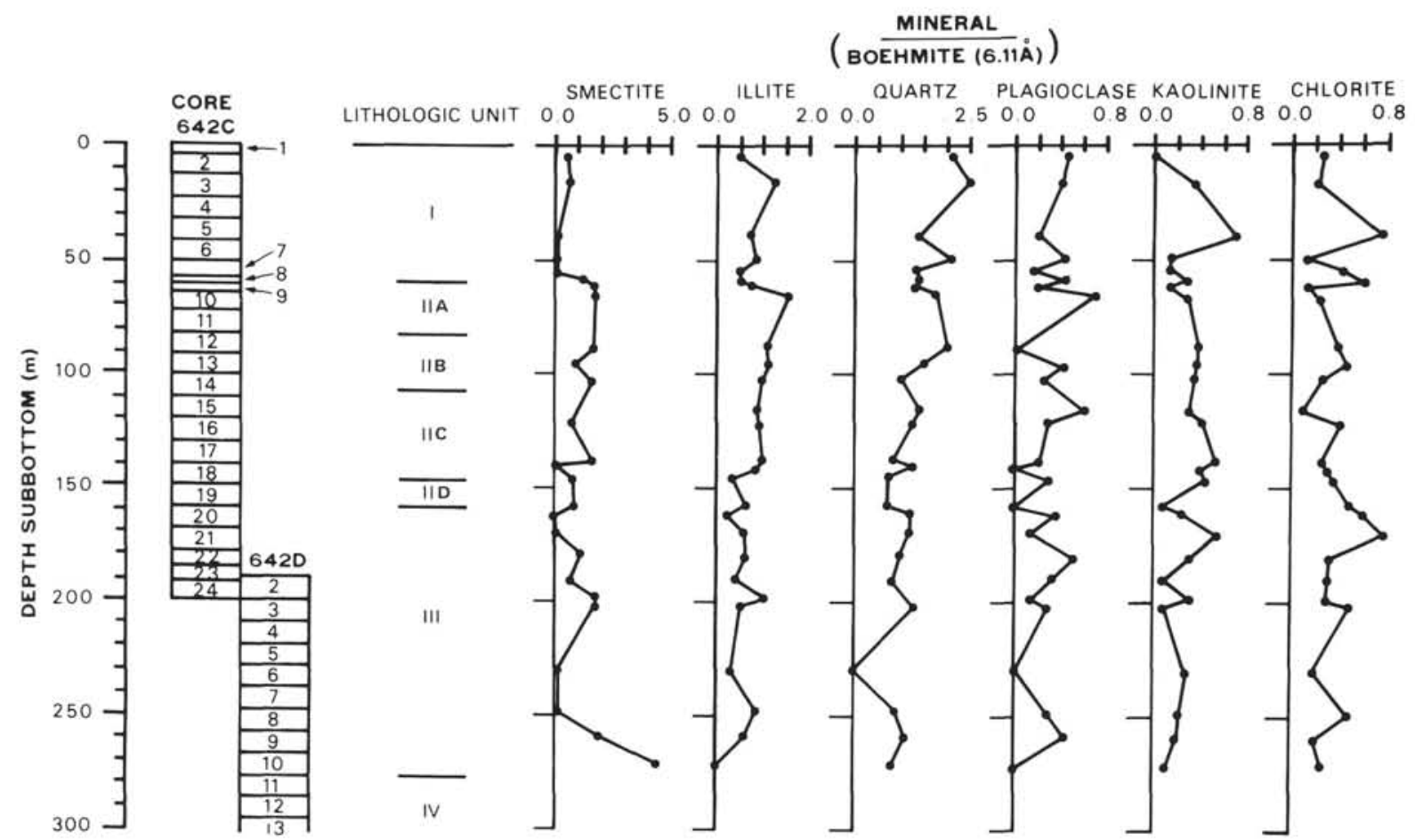

Figure 2. Mineral abundance data (XRD peak-area ratios) at ODP Site 642, plotted as a function of stratigraphic position. Smectite abundances increase downcore, quartz and illite abundances decrease downcore, and plagioclase feldspar, kaolinite, and chlorite abundances vary irregularly.

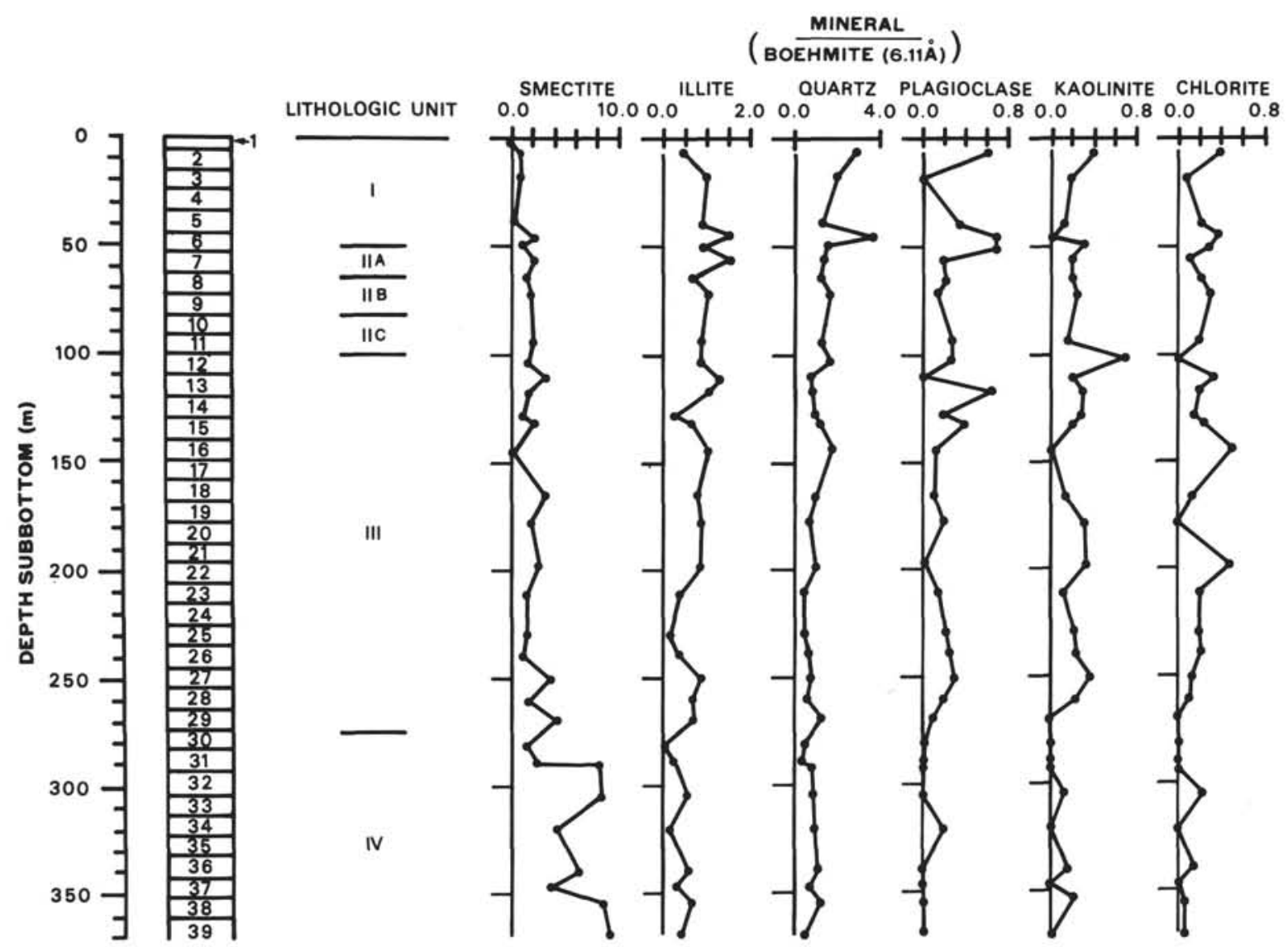

Figure 3. Mineral abundance data (XRD peak-area ratios) at ODP Site 643, plotted as a function of stratigraphic position. Downcore abundance variations are similar to those exhibited at Site 642 (see Fig. 2). 
olinite formation existed during the Carboniferous and the Jurassic periods.

Kaolinite-rich deposits of these ages are not widespread on land, however, suggesting that most of this material was subsequently removed by erosion, perhaps during Tertiary uplift (Vogt, et al., 1981). The kaolinite, which is the stable end-product of chemical weathering under most natural conditions (Garrels and McKenzie, 1971), was not affected by the subsequent erosional events and has been recycled to present depositional sites throughout the North Sea and the Norwegian-Greenland Sea. As a result, the kaolinite abundances record an inherited signature of provenance, and do not reflect late Tertiary and Quaternary weathering conditions in Scandinavian source areas.

Because of its compositional instability during repeated cycles of chemical weathering, chlorite is more easily interpreted as a first-cycle sedimentary component, but shows no coherent pattern of change at either Site 642 or Site 643 . Instead, the variable chlorite abundances suggest that physical weathering of some basic source rocks has occurred throughout the time of deposition of this sequence; the abundance variations may reflect both local evolution of source-rock composition and slight changes in the balance between physical and chemical weathering processes. Both of these variations can be expected in an eroding highland terrain, such as the Scandinavian Caledonides.

\section{Provenance Interpretation Based on Principal-Components Analysis}

The peak-area ratio data were subjected to principal-components analysis (PCA) to identify multimineral source-area compositions within each data set. Data sets from each site were analyzed separately to allow for different sources at each site. The source-area compositions identified by these analyses are then interpreted as provenance indicators. Results of the PCA of Site 642 are shown in Figures 4 and 5, while Site 643 results are given in Figures 6 and 7.

At Site 642 , the first three factors identified by the initial PCA account for $75 \%$ of the total variance and include all of the minerals considered. To simplify geologic interpretations, only those three factors were used in a varimax rotation of the PCA results. Because only three factors were rotated, those three factors account for $100 \%$ of the data variance; the variance is distributed rather evenly across the three varimax-rotated factors. Standardized scoring coefficients for each factor are plotted in Figure 4, and can be summarized and interpreted as follows:

1. Factor 1 is dominated by high positive coefficients for quartz and feldspar, and an intermediate positive score for illite. The largest negative coefficients are for smectite and, to a lesser extent, kaolinite. The association of quartz, plagioclase, and illite is interpreted to reflect a moderately-weathered (temperate conditions) continental source containing such lithologies as granites, acidic metamorphic rocks, and immature preexisting sedimentary units. The association of smectite and kaolinite is less straightforward to interpret, but appears to represent sources that dilute the continental input, especially materials produced by moderate weathering of basic igneous rocks and components recycled from mature preexisting sediments.

2. Factor 2 is dominated by a high positive coefficient for smectite and a high negative coefficient for chlorite. No other variables have coefficients of similar magnitude. The smectitedominated source-area composition is interpreted to record input from a moderately-weathered basic igneous terrane. While such regions do exist on the Scandinavian landmass (Holtedahl, 1960; Nicholson, 1974), this end-member may also record insitu alteration of volcanic materials. The chlorite-dominated source-area composition is interpreted to record input from ba- sic igneous and/or metamorphic rocks dominated by physical weathering. The two source areas indicated by Factor 2, therefore, reflect a similar lithology, but contrast development under chemical vs. physical weathering conditions.

3. Factor 3 is dominated by high positive coefficients for illite and kaolinite. Illite is commonly interpreted as a product of temperate (middle-latitude) weathering of acidic rocks, while kaolinite is developed by significant chemical weathering, especially from acidic rocks. The association of illite and kaolinite, therefore, reflects a contribution from moderately- to intensively-weathered acidic rocks; the source rocks may be igneous and metamorphic complexes, or may actually be preexisting sedimentary units. The evidence discussed previously suggests that recycled sediments can be an important contributor in this region, while acidic, igneous and metamorphic sources are also available.

The source area supplying quartz, feldspar, and illite (positive Factor 1) and the source area supplying illite and kaolinite (positive Factor 3 ) both record input from moderately-weathered continental lithologies. The distinction of the two source areas, however, may reflect a subtle difference in sediment composition. The source area indicated by positive Factor 1 values is dominated by the two nonphyllosilicate phases considered in this analysis; since nonphyllosilicate phases become more abundant as sediment grain size increases, the apparent importance of that source area may depend on both sample grain size and composition. The source area indicated by Factor 3 then dominates in finer grained samples with a continentally-derived provenance (including recycled sediments). The source areas identified by Factor 2 are basic in provenance, but represent physical and chemical weathering products.

Sample loadings on the three factors are plotted in Figure 5 as a function of stratigraphic position at Site 642 . Changes in loadings generally do not correspond to boundaries between lithologic units, reflecting the importance of biogenic components in defining those units. Factor 1 loadings generally decrease downcore, with a marked shift from predominantly positive loadings above 130 mbsf to predominantly negative loadings below that level. This transition records the increasing importance of acidic terrigenous components, especially silts, upsection. The increase in Factor 3 loadings upsection also records the increase in continental terrigenous material, although Factor 3 loadings become strongly positive below the transition in Factor 1 loadings. The earlier importance of Factor 3 suggests that the finer grained illites and kaolinites were first introduced before the continental quartz and plagioclase of Factor 1 . Such a sequence is predicted if the kaolinites and illites of Factor 3 were derived from preexisting sedimentary sequences and weathering profiles developed atop acidic igneous and metamorphic basement; the second-generation sediments would then be recycled prior to erosion of the basement complexes, producing a compositional inversion in the offshore sediments.

Loadings on Factor 2 are more variable downcore, with strong negative values near the surface and approximately 170 mbsf, strong positive values below $250 \mathrm{mbsf}$, and relatively low values elsewhere. The strong positive loadings reflect the importance of smectite, probably authigenic, at the base of the sedimentary section, while the strong negative loadings above $50 \mathrm{~m}$ reflect the importance of glacially-derived chlorite. The remainder of the core is influenced by products from variable weathering of basic sources. The temporal pattern of source-area importance and climatic variation at Site 642 will be discussed in more detail during a comparison with the Site 643 results.

For the Site 643 peak-area ratio data, the first three components identified by PCA accounted for $77 \%$ of the original data variance. To simplify interpretation and because all minerals were included in these factors, only the three most important 
UNROTATED

$\begin{array}{cc}\text { FACTOR } & \text { VARIANCE } \\ 1 & 31.3 \% \\ 2 & 27.6 \% \\ 3 & 16.2 \% \\ 4 & 11.0 \% \\ 5 & 9.6 \%\end{array}$

VARIMAX ROTATION

$\begin{array}{cc}\text { FACTOR } & \text { VARIANCE } \\ 1 & 39.6 \% \\ 2 & 31.2 \% \\ 3 & 29.1 \%\end{array}$

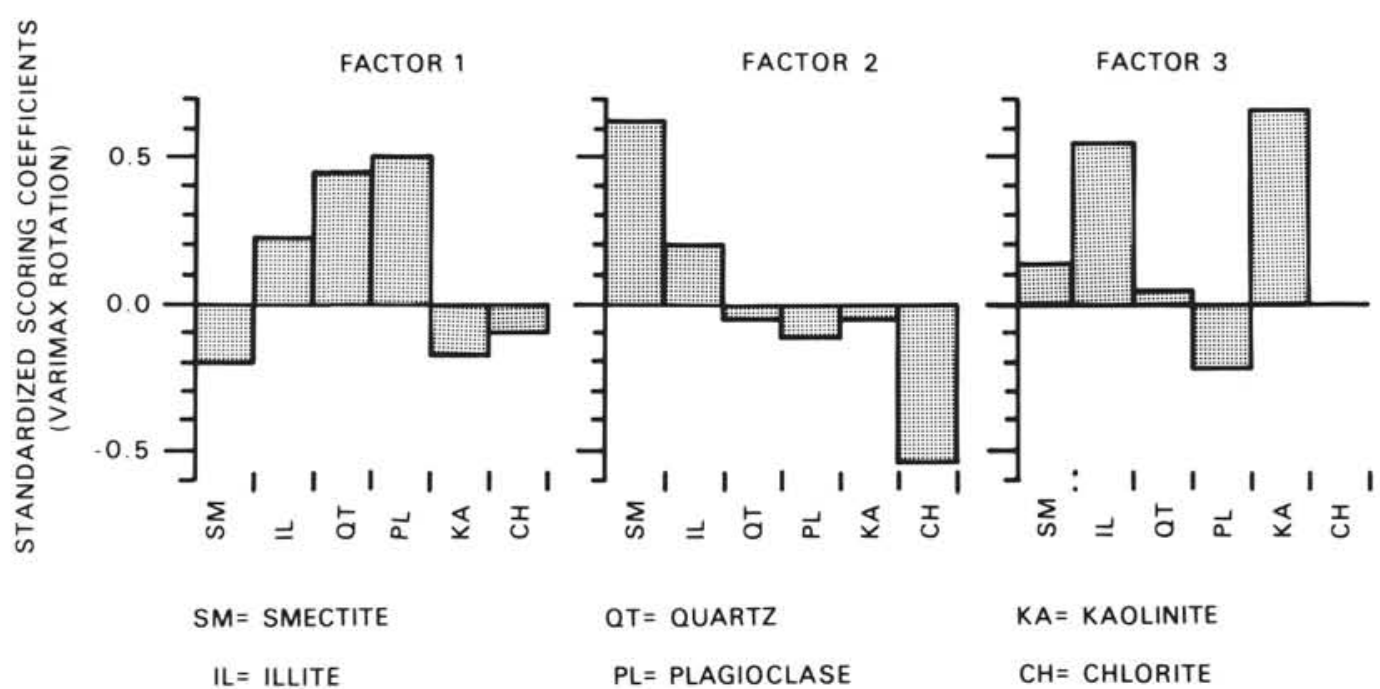

Figure 4. Summary of the results of a principal-components analysis of the Site 642 mineral abundance data. Only the first three factors were included in the varimax rotation, and those three factors were assumed to account for $100 \%$ of the data variance. Factor 1 is interpreted to indicate a continental source, Factor 2 records basic source areas under physical and chemical weathering conditions, and Factor 3 records a source area of recycled sediments.

factors were included in the varimax rotation. Although some differences do exist, the three factors defined by varimax rotation at Site 643 are generally similar to those identified at Site 642 (Fig. 6; compare with Fig. 4). At Site 643, Factor 1 is dominated by high positive coefficients for illite and quartz, two phases in the continental source area identified by Factor 1 at Site 642. Smectite has a moderate positive coefficient in Factor 1 at Site 643, reflecting the higher average smectite content at Site 643 than at Site 642 (compare Figs. 2 and 3). Factor 2 at Site 643 is dominated by a positive smectite coefficient and a negative chlorite coefficient; as at Site 642 , Factor 2 identifies basic source areas with chemical or physical weathering, respectively. Factor 3 at Site 643 is dominated by a positive coefficient for kaolinite, interpreted as a source area of preexisting sedimentary rocks. Factor 3 at Site 642 was interpreted similarly.

Loadings on the three varimax-rotated factors at Site 643 are plotted in Figure 7 as a function of stratigraphic position. As at Site 642, Factor 1 loadings decrease downcore, reflecting the decreased importance of continentally-derived temperate weathering products. The shift from positive to negative loadings on Factor 1 is less abrupt at Site 643 than at Site 642, probably reflecting the increased importance of smectite in the continental source area (positive Factor 1) at Site 643. Factor 2 loadings at Site 643 increase downcore, recording the dominance of smectite below approximately $280 \mathrm{mbsf}$. As discussed previously this smectite is probably authigenic, although a detrital contribution of smectite is also possible. Factor 2 loadings are predominantly negative above approximately $250 \mathrm{mbsf}$, indicating an increased input of detrital, physically-weathered chlorites. High positive loadings on Factor 3, the indicator of recycled kaolinite, occur irregularly through Site 643, but are most common between 100 mbsf and 270 mbsf. This distribution suggests a sporadic input of preexisting sediments as the Scandinavian landmass was uplifted, and isolated regions of older sediments were eroded.

The principal-components analyses of data from Sites 642 and 643 have identified generally similar sources and provenance histories for these two sites. This history is summarized in Table 1, along with weathering conditions inferred from the sample mineralogy, especially the clay mineralogy. This inferred record of paleoclimate is valuable for comparison with published paleoclimatic histories based on other data.

\section{Paleoclimatic Interpretation}

The paleoclimatic record summarized in Table 1 calls for temperate and moist weathering conditions for most of the interval from the early Miocene to the late Pliocene. A notable exception occurs near the middle Miocene/late Miocene boundary, when chlorite from the physically weathered basic source area becomes important at Site 642. This input is interpreted to reflect cool, dry conditions. The Miocene-Pliocene section contains a number of hiatuses of unknown length, however, so that the record preserved at Sites 642 and 643 is incomplete. Within these constraints, a dominance of temperate, moist conditions is indicated.

Berggren and Schnitker (1983) summarize Cenozoic marine environments of the North Sea-Norwegian-Greenland Sea region, and indicate that the early Miocene was a time of warming. This climatic trend was driven by closure of the Tethys be- 


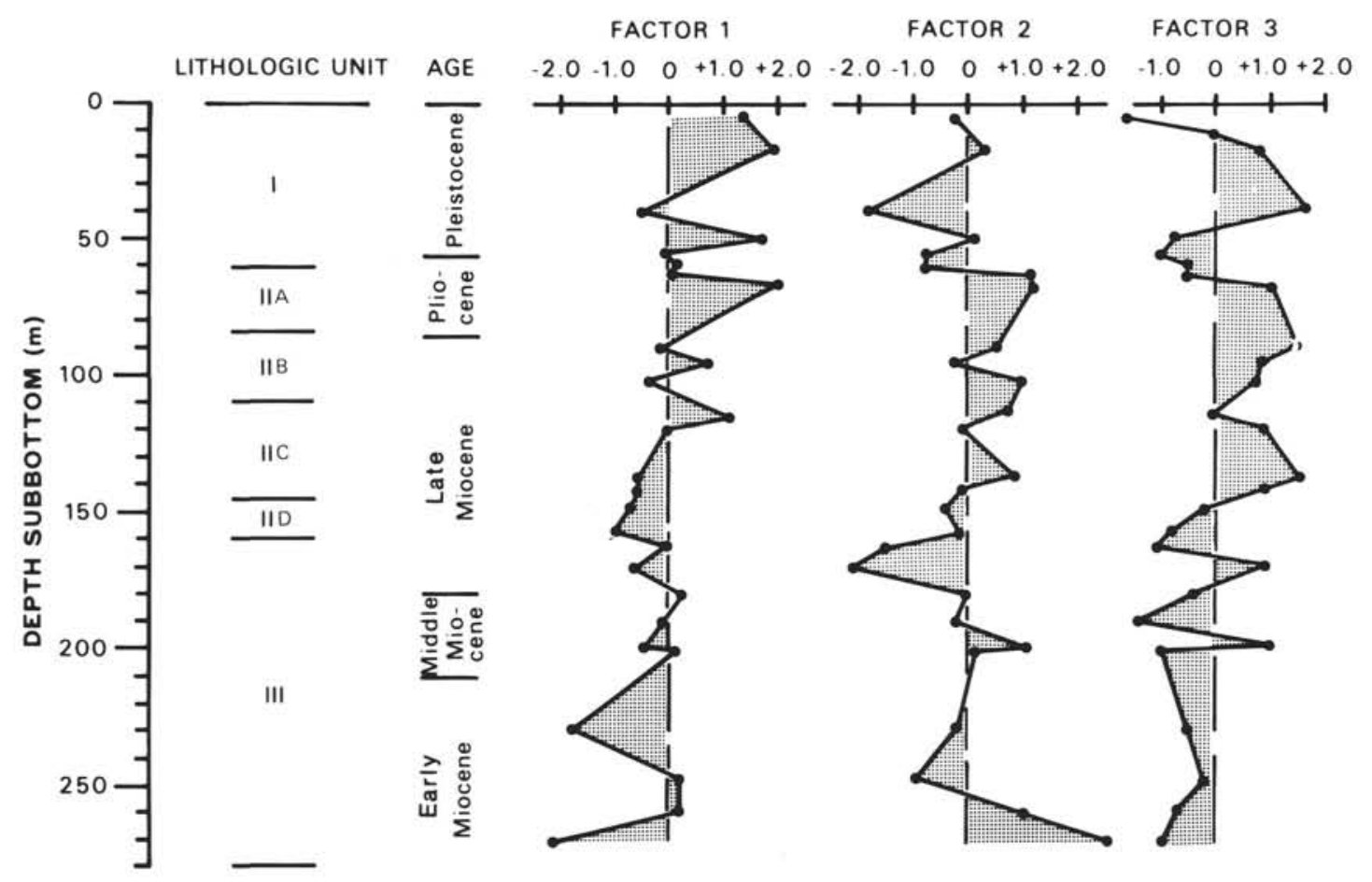

Figure 5. Loadings on the three varimax-rotated factors identified for Site 642 . The continental source becomes more important upsection, as does a basic source supplying physically-weathered products (negative Factor 2). Chemical weathering of basic source lithologies dominates near the base of this section. Recycled sediment input varies through Site 642 .

tween Africa and Europe, which increased the flow of warm, saline waters into the North Atlantic. Such circulation would produce continental climates suitable for temperate humid weathering, as are observed at Sites 642 and 643. A major oxygen-isotope and micropaleontologic shift at approximately $15 \mathrm{Ma}$, near the beginning of the middle Miocene, records a global cooling event that continued through the late Miocene; the regional effect of cooler and drier conditions may be recorded by the chlorite-rich pulses near the middle Miocene/upper Miocene boundary at Site 642 . Temperate weathering products again became dominant at Sites 642 and 643 during the late Miocene. The return to temperate weathering products may be explained by depletion of appropriate source lithologies, local climatic variations, or reworking of previously-developed temperate weathering products. A palynologic sequence in the southwestern Netherlands contains an upper Miocene record suggestive of fairly uniform, temperate to cool-temperate, nonmaritime conditions (Suc and Zagwijn, 1983). Such conditions generally favor illite formation, although smectites may be produced from basic source rocks if erosion rates are relatively low.

Sediments at Sites 642 and 643 indicate continued temperatemoist weathering conditions for most of the Pliocene, although the record is incomplete. The upper Pliocene is marked by a dramatic shift to sediments from the physically-weathered basic source. The marine record suggests a return of warm conditions to the North Atlantic at the beginning of the Pliocene, with major cooling in the late Pliocene (Berggren and Schnitker, 1983). The mineral data agree with this sequence. Palynologic evidence from the southwestern Netherlands records temperate to warmtemperate moist conditions up to the late Pliocene, with several cycles of warm-moist to cool conditions superimposed (Suc and Zagwijn, 1983).
Upper Pliocene and Pleistocene sediments at Sites 642 and 643 record the effects of glacial/interglacial conditions in several ways (Eldholm, Thiede, Taylor, et al., 1987), including mineral composition (see Table 1). Such climatic fluctuations are also widely recognized in the marine and pollen records (Berggren and Schnitker, 1983; Suc and Zagwijn, 1983). Within the limitations of our sampling interval and the completeness of the stratigraphic sections at Sites 642 and 643, therefore, the major climatic changes inferred for this region can be recognized by changes in sediment formation, especially as recorded by sourcearea compositions dominated by the clay minerals.

\section{SUMMARY}

Bulk compositions of the nonbiogenic fraction of samples from ODP Sites 642 and 643 in the Norwegian-Greenland Sea have been determined by X-ray diffraction, using an internalstandard method. These data were used to investigate patterns of sediment provenance (source-rock lithology and weathering). Important phases are smectite, chlorite, illite, kaolinite, quartz, and plagioclase feldspar. Compositional variations generally do not correlate with boundaries between lithologic units, reflecting the importance of biogenic constituents in defining the lithologic units. At both sites, smectite abundances increase downcore, while quartz and illite abundances decrease. Plagioclase feldspar, kaolinite, and chlorite abundances are variable throughout the length of the cores.

The upcore increase in quartz and illite abundances suggests an increase in the importance of moderately-weathered acidic source rocks through time. The acidic source replaces a basic source, indicated by abundant smectite that is dominant near the base of each section. This smectite either is detrital or developed in situ by alteration of volcanic ash. Kaolinite in these sed- 

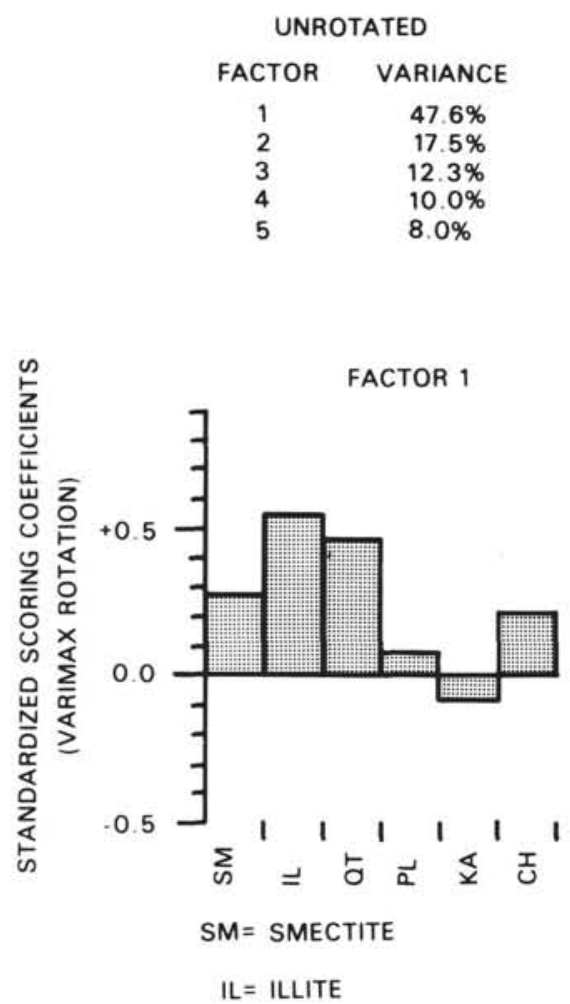

VARIMAX ROTATION

$\begin{array}{cc}\text { FACTOR } & \text { VARIANCE } \\ 1 & 43.6 \% \\ 2 & 29.7 \% \\ 3 & 26.7 \%\end{array}$

FACTOR 2

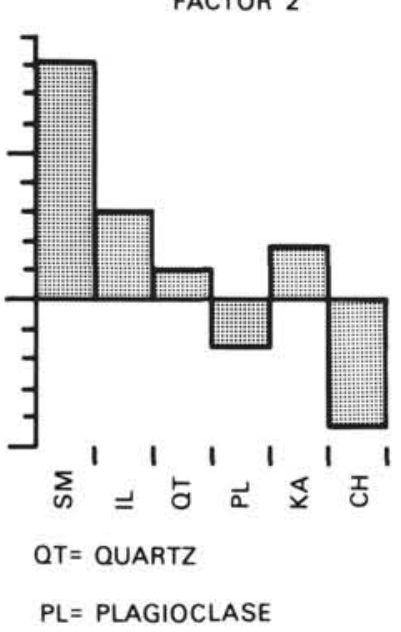

FACTOR 3

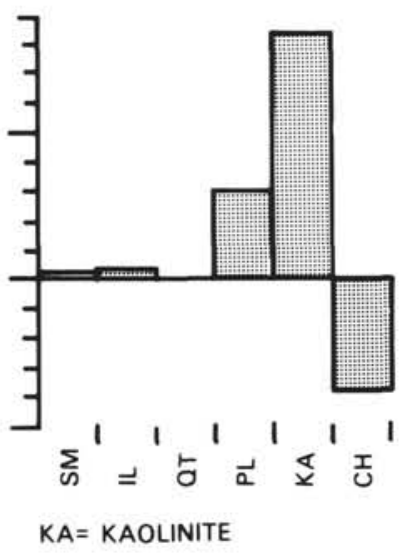

$\mathrm{CH}=\mathrm{CHLORITE}$

Figure 6. Summary of the results of a principal-components analysis of the Site 643 mineral abundance data. Only the first three factors were included in the varimax rotation, and these three factors were assumed to account for $100 \%$ of the data variance. Factors identified at Site 643 are directly comparable to those identified at Site 642 (see Fig. 4).

iments was first formed in Paleozoic and Mesozoic sedimentary rocks and paleosols and does not record Neogene weathering conditions on adjacent landmasses. The reported distribution of kaolinite, however, attests to the once widespread distribution of these pre-Cenozoic sequences. Chlorite is a primary sedimentary component, and its variable abundance results from the heterogeneity of source lithology and weathering regime on the Scandinavian landmass.

Principal-components analysis of the mineral abundance data has identified four major source-area compositions at each site; these four source areas are approximately the same for the two data sets. The first source area is dominated by associations of quartz and illite \pm plagioclase, and is interpreted to represent an acidic igneous/metamorphic source subject to moderate weathering. Such lithologies are common on the Scandinavian landmass. The second source area consisted of basic continental rocks subject to physical weathering and supplied chlorite. The third source area contained basic materials subject to chemical alteration, either on land or in situ, and supplied smectite. The fourth source area consisted of Paleozoic and Mesozoic sediments, and supplied recycled kaolinites.

The general stratigraphic record of source-area influence suggests a predominance of temperate humid weathering regimes from early Miocene through late Pliocene time, with a short-lived shift to cool dry weathering near the start of the late Miocene. The late Pliocene and Pleistocene are characterized by repeated mixtures of temperate and cool-dry weathering products, developed during repeated glacial and interglacial conditions. Similar paleoclimatic sequences have been interpreted previously from marine micropaleontologic and terrestrial palynologic data from this area. The interpretation of a complemen- tary climatic history from the terrigenous components suggests that careful study of such components may provide paleoclimatic insight when paleontologic evidence is unavailable.

\section{ACKNOWLEDGMENTS}

The author wishes to thank the officers and crew of the SEDCO BP 471 and the ODP technical staff for their efforts during Leg 104. Kenneth Coats assisted with sample preparation, Dr. William Ausich facilitated the principal-components analysis, Helen Hayes typed the manuscript, Karen Tyler drafted the illustrations, and David Little photographed the illustrations; their assistance is gratefully acknowledged. Dr. D. Murray and three anonymous reviewers supplied helpful comments; interpretations expressed here are the responsibility of the author.

\section{REFERENCES}

Berggren, W. A., and Schnitker, D., 1983. Cenozoic marine environments in the North Atlantic and the Norwegian-Greenland Sea. In Bott, M. H. P., Saxov, S., Talwani, M., and Thiede, J. (Eds.), Structure and Development of the Greenland-Scotland Ridge: New York (Plenum), 495-548.

Biscaye, P. E., 1965. Mineralogy and sedimentation of recent deep-sea clay in the Atlantic Ocean and adjacent seas and oceans. Bull. Geol. Soc. Am., 76: 803-832.

Blatt, H., Middleton, G., and Murray, R., 1980. Origin of Sedimentary Rocks (2nd ed.): Englewood Cliffs, N.J. (Prentice-Hall).

Bugge, T., Løfaldli, M., Maisey, G. H., Rokoengen, K., Skaar, F. E., and Thusu, B., 1975. Geological investigation of a Lower Tertiary/ Quaternary Core, offshore Trondelag, Norway. Bull. Nor. Geol. Unders., 316:253-269.

Bugge, T., Knarud, R., and Mørk, A., 1984. Bedrock geology on the mid- Norwegian continental shelf. In Spencer, A. M., et al. (Eds.), Petroleum Geology of the North European Margin: London (Graham and Trottman), 271-283. 
Dalland, A., 1975. The Mesozoic rocks of Andøy, northern Norway. Bull. Nor. Geol. Unders., 316:271-287.

Davis, J. C., 1986. Statistics and Data Analysis in Geology (2nd ed.): New York (Wiley).

Eisma, D., and van der Gaast, S. J., 1983. Terrigenous late Quaternary sediment components north and south of the Scotland-Greenland Ridge and in the Norwegian Sea. In Bott, M. H. P., Saxov, S., Talwani, M., and Thiede, J. (Eds.), Structure and Development of the Greenland-Scotland Ridge: New York (Plenum), 607-635.

Eldholm, O., Thiede, J., Taylor, E., et al., 1987. Proc. ODP, Init. Repts. (Pt. A), 104: College Station, TX (Ocean Drilling Program).

Emelyanov, E. M., Blazchishin, A. I., Kharin, G. S., Lozovaya, N. G., and Zangalis, K. P., 1978. Mineral and chemical composition of sediments of the Vøring Plateau, DSDP Leg 38. In Talwani, M., Udintsev, G., et al., Init. Repts. DSDP, Suppl., 38, 39, 40, 41: Washington (U.S. Govt. Printing Office), 31-44.

Fan, P. F., 1976. Recent silts in the Santa Clara River drainage basin, southern California: a mineralogical investigation of their origin and evolution. J. Sediment. Petrol., 46:802-812.

Friis, H., Nielsen, O. B., Friis, E. M., and Balme, B. E., 1979. Sedimentological and paleobotanical investigations of a Miocene sequence at Lavsbjerg, Central Jutland, Denmark. Dan. Geol. Unders., Arbog, 1979:51-67.

Garrels, R. M., and McKenzie, F. T., 1971. Evolution of Sedimentary Rocks: New York (W. W. Norton and Co.).

Gibbs, R. J., 1967. Quantitative X-ray diffraction analysis using clay mineral standards extracted from the samples to be analyzed. Clay Mineral., 7:79-90.

Griffin, J., Windom, H., and Goldberg, E. D., 1968. The distribution of clay minerals in the world ocean. Deep Sea Res., 15:433-459.

Halvorsen, S., 1974. Four sediment cores from the continental shelf outside Trondelag. Bull. Nor. Geol. Unders., 304:21-31.

Holtedahl, 0., 1960. Geology of Norway. Bull. Nor. Geol. Unders., 208: $1-540$.

Holtedahl, H., Haldorsen, S., and Vigran, J. O., 1974. Two sediment cores from the Norwegian continental shelf between Haltenbanken and Froyabanken $\left(64^{\circ} 06^{\prime} \mathrm{N}, 7^{\circ} 39^{\prime} \mathrm{E}\right)$. Bull. Nor. Geol. Unders., 304: $1-20$.

Hurst, A., 1985. The implications of clay mineralogy to palaeoclimate and provenance during the Jurassic in NE Scotland. Scott. J. Geol., 21:143-160.

Karlin, R., 1980. Sediment sources and clay mineral abundances off the Oregon coast. J. Sediment. Petrol., 50:543-560.

Kolla, V., and Biscaye, P. E., 1973. Clay mineralogy and sedimentation in the East Indian Ocean. Deep Sea Res., 20:727-738.

Kolla, V., Henderson, L., and Biscaye, P. E., 1976. Clay mineralogy and sedimentation in the West Indian Ocean. Deep Sea Res., 23: 949-963.

Krissek, L. A., 1982. Sources, dispersal, and contributions of finegrained terrigenous sediments on the Oregon and Washington continental slope [Ph.D. dissert.]. Oregon State University, Corvallis.

Krissek, L. A., 1984. Continental source area contributions to finegrained sediments on the Oregon and Washington continental slope. In Stow, D. A. V., and Piper, D. J. W. (Eds.), Fine-Grained Sediments: Deep Water Processes and Facies: London (Blackwell Scientific), 363-375.

Krissek, L. A., and Scheidegger, K. F., 1983. A comparison of clay mineral abundances estimated by a semiquantitative and quantitative method. Geol. Soc. Am. Abstracts with Programs, 15:254. (Abstract)
Lisitzin, A. P., 1972. Sedimentation in the world ocean. Spec. Publ. 17: Tulsa, OK (Society of Economic Paleontologists and Mineralogists).

Nicholson, R., 1974. The Scandinavian Caledonides. In Nairn, A.E.M., and Stehli, F. G. (Eds.), The Ocean Basins and Margins (Vol. 2, The North Atlantic: New York (Plenum), 161-203.

Nielsen, 0. B., 1979. A sedimentological mineralogical investigation of the Tertiary sediments from the borehole M-2X in Central Trough, North Sea. Dan. Geol. Unders., Årbog 1979:41-50.

Nilsen, T. H., and Kerr, D. R., 1978. Turbidites, redbeds, sedimentary structures, and trace fossils observed in DSDP Leg 38 cores and the sedimentary history of the Norwegian-Greenland Sea. In Talwani, M., Udintsev, G., et al., Init. Repts. DSDP, Suppl., 38, 39, 40, 41: Washington (U. S. Govt. Printing Office), 259-288.

Pinet, P. R., and Morgan, J. W., Jr., 1979. Implication of clay provenance studies in two Georgia estuaries. J. Sediment. Petrol., 49:575580 .

Rosato, V. J., and Kulm, L. D., 1981. Clay mineralogy of the Peru continental margin and adjacent Nazca Plate: Implications for provenance, sea level changes, and continental accretion. In Kulm, L. D., and others (Eds.), Nazca Plate: Crustal Formation and Andean Convergence. Memoir 154: Boulder, CO (Geological Society of America), 545-568.

Rosenqvist, I. Th., 1985. Mineralogy of material from the upper Quaternary Skagerrak sediment core GIK 15330-4. Nor. Geol. Tidsskr., 65:73-75.

SAS Institute, Inc., 1985. SAS User's Guide: Statistics (5th ed.): Cary, N.C. (SAS Institute, Inc.).

Scheidegger, K. F., and Krissek, L. A., 1982. Dispersal and deposition of eolian and fluvial sediments off Peru and northern Chile. Geol. Soc. Am. Bull., 93:150-162.

Sturt, B. A., Dalland, A., and Mitchell, J. L., 1979. The age of the subMid-Jurassic tropical weathering profile of Andøya, northern Norway, and the implications for the late Palaeozoic paleography in North Sea. Dan. Geol. Unders., Arbog 1979:41-50.

Suc, J. P., and Zagwijn, W. H., 1983. Plio-Pleistocene correlations between the northwestern Mediterranean region and northwestern Europe according to recent biostratigraphic and paleoclimatic data. Boreas, 12:153-166.

Talwani, M., and Udintsev, G., et al., 1976. Init. Repts. DSDP, 38: Washington (U.S. Govt. Printing Office).

Vogt, P. R., Perry, R. K., Feden, R. H., Fleming, H. S., and Cherkis, N. Z., 1981. The Greenland-Norwegian Sea and Iceland Environment: Geology and Geophysics. In Nairn, A. E. M., Churkin, M., Jr., and Stehli, F. G. (Eds.), The Ocean Basins and Margins (Vol. 5, The Arctic Ocean): New York (Plenum), 493-598.

White, S. M., 1978a. X-ray mineralogy of sediments, DSDP Leg 38. In Talwani, M., Udintsev, G., et al., Init. Repts. DSDP, Suppl., 38, 39, 40, and 41: Washington (U.S. Govt. Printing Office), 437-443.

White, S. M., 1978b. Sediments of the Norwegian-Greenland Sea, DSDP Leg 38. In Talwani, M., Udintsev, G., et al., Init. Repts. DSDP, Suppl., 38, 39, 40, and 41: Washington (U.S. Govt. Printing Office), 193-258.

Wilding, L. P., Smeck, N. E., and Drees, L. R., 1977. Silica in soils: Quartz, cristobalite, tridymite, and opal. In Dixon, J. B., and Weed, S. B. (Eds.), Minerals in Soils Environments: Madison, Wisc. (Soil Science Society of America), 471-552.

Date of initial receipt: 25 March 1987

Date of acceptance: 25 March 1988

Ms 104B-113 


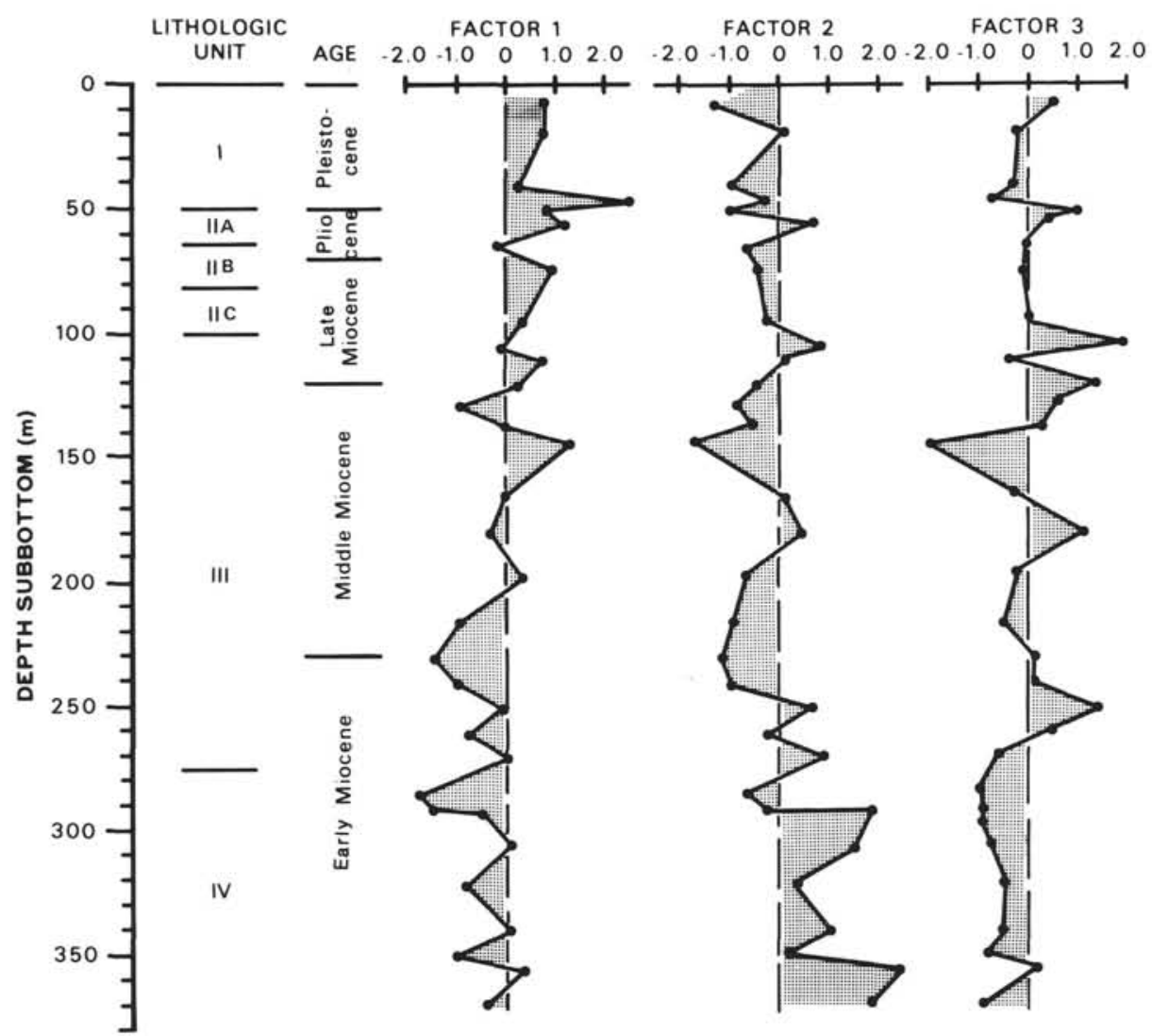

Figure 7. Loadings on the three varimax-rotated factors identified for Site 643. Temporal variations in source-area influence are similar to those displayed at Site 642.

Table 1. Summary of the provenance history at Sites 642 and 643 , as interpreted from the results of principal-components analyses. Paleoclimatic inferences are strongly controlled by the clay minerals present; see the text for a comparison of this paleoclimatic record with others proposed for the North Sea/Norwegian-Greenland Sea area.

\begin{tabular}{|c|c|c|c|c|}
\hline Age & $\begin{array}{c}\text { Factor } 1 \\
\text { Continental source }\end{array}$ & $\begin{array}{c}\text { Factor } 2 \\
\text { Basic source }\end{array}$ & $\begin{array}{l}\text { Factor } 3 \\
\text { Recycled } \\
\text { sediments }\end{array}$ & $\begin{array}{l}\text { Inferred } \\
\text { Weathering } \\
\text { Conditions }\end{array}$ \\
\hline Pleistocene & $\begin{array}{l}\text { Major input, moderate } \\
\text { chemical weathering }\end{array}$ & $\begin{array}{l}\text { Major input, physical } \\
\text { weathering }\end{array}$ & $\begin{array}{l}\text { Variable } \\
\text { input }\end{array}$ & $\begin{array}{l}\text { Alternating temperate/ } \\
\text { moist and cool/ } \\
\text { dry }\end{array}$ \\
\hline Pliocene & $\begin{array}{l}\text { Major input, moderate } \\
\text { chemical weathering }\end{array}$ & $\begin{array}{l}\text { Variable input, moderate } \\
\text { chemical weathering }\end{array}$ & $\begin{array}{l}\text { Variable } \\
\text { input }\end{array}$ & Temperate/moist \\
\hline $\begin{array}{l}\text { Late } \\
\qquad \text { Miocene }\end{array}$ & $\begin{array}{l}\text { Minor input, moderate } \\
\text { chemical weathering }\end{array}$ & $\begin{array}{l}\text { Variable input, moderate } \\
\text { chemical weather- } \\
\text { ing; increased } \\
\text { physical weathering } \\
\text { at base ( } 642)\end{array}$ & $\begin{array}{l}\text { Major } \\
\text { input }\end{array}$ & $\begin{array}{l}\text { Temperate/moist } \\
\text { Cool/dry }\end{array}$ \\
\hline $\begin{array}{l}\text { Middle } \\
\text { Miocene }\end{array}$ & $\begin{array}{l}\text { Variable input, moder- } \\
\text { ate chemical } \\
\text { weathering }\end{array}$ & $\begin{array}{l}\text { Variable input, moderate } \\
\text { chemical weather- } \\
\text { ing; low input at } \\
642\end{array}$ & $\begin{array}{l}\text { Variable to } \\
\text { low } \\
\text { input }\end{array}$ & Temperate/moist \\
\hline $\begin{array}{l}\text { Early } \\
\text { Miocene }\end{array}$ & Minor input & $\begin{array}{l}\text { Major input, moderate } \\
\text { chemical weathering } \\
\text { (in situ?) }\end{array}$ & $\begin{array}{l}\text { Minor } \\
\text { input }\end{array}$ & Temperate/moist \\
\hline
\end{tabular}

